\title{
An Investigation Into Credit Card Debt Among College Students
}

Dylan Williams, Southeastern Louisiana University, USA

Brian Waterwall, Southeastern Louisiana University, USA

Tiffany Giardelli, Southeastern Louisiana University, USA

\begin{abstract}
It is no surprise that the amount of credit card debt and outstanding loan balances of college students is increasing every year. College students are heavily targeted by credit companies through the use of e-mail, campus booths, and standard mail. The reason for these solicitations is because of the soaring expense levels of college students and the potential that such a large group has to add profits to the issuing firm. Marketers are interested in credit card usage of students to determine the best methods for gaining market share in this emergent market. Credit card and loan usage patterns of college students are investigated.
\end{abstract}

Keywords: Student debt, credit card usage

\section{INTRODUCTION}

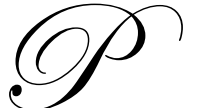

urchasing on credit is a widespread practice. Fifty to eighty years ago, credit was not an option; if a person did not have the money for a purchase, it was simply not affordable. Credit has become readily available to almost anyone who wants it, especially college students. College students have become a budding faction of wealth in the credit card market. In recent years, credit card companies have been cashing in on this rapidly growing segment by setting up booths on university campuses as well as creating alliances with colleges for the exclusive rights to advertise their credit cards (Silver-Greenberg, 2008; Souccar, 1999). These companies have lured students with free giveaways such as t-shirts, Frisbees, food and cash (Palmer, 2008; SilverGreenberg, 2007). Students must be careful with their choices of creditors or face the fact that their interest rate may steadily increase. Simon and Whelan (2002) stated that rates can range from very low, “...8.9\% on Blue for Students," to very high "nearly $18 \%$ on a Discover Card...". As much as $9 \%$ of college students use credit to pay for their monthly bills and purchases. The college-bound generation is also receiving credit card applications even before they set foot on a college campus. Companies such as Capital One, Citibank, Discover Financial Services and Wells Fargo have sent out direct-mail offers to parents of 16 to 18 year olds, and MBNA sent almost 100,000 to incoming freshmen (Simon and Whelan, 2002). Some parents insist on their children obtaining credit cards before they arrive at school for emergency situations and building credit purposes, but often times their children have other ideas.

Students figure: I'll live like I want to now and then when I get a job it will be easy to pay it back (Lazarony, 1998). This seems to be the philosophy of many college students. Who could resist with credit card companies handing out applications through standard mail, e-mail and even between classes and when student loans are not required to be paid back until after graduation. What students often forget is that it must be repaid. A student with an $18 \%$ interest rate and paying minimum payments would take over 12 years to pay off a balance of $\$ 1,000$ on a credit card (Lazarony, 1998). Students continue to fill-out applications in spite of the major responsibility.

In 2002, Nellie Mae conducted a study showing the percentage of students holding at least one card has risen 24\% since 1998 (Nellie Mae, 2002). However, an additional study by Palmer in 2006 found that possession of a card in 18 to 20 year olds dropped 10\% from 50 in 2002 (Palmer, 2008). Reasons for this decline include better 
education, greater use of debit cards, and the shifting of debt to student loans. One other study in 2007 found that only 38\% of college students had a credit card in their name (Hall, 2008). The number of students that hold a credit card in their name has been decreasing since the Nellie Mae study, but the average loan debt has begun to rise.

Palmer's study found that for the 2003-2004 school year, the average student loan debt from a four-year public school totaled $\$ 15,500$ while the total just ten years ago was only $\$ 8,800$. A reason for this may be students are taking out loans to pay off their credit card debt (Palmer, 2008). On July $1^{\text {st }}, 2006$ federal student loans had a fixed rate of $6.8 \%$, the highest in five years. Average debt amounts for graduates totaled $\$ 19,000$ while undergraduates now owe over $\$ 40,000$ (Block, 2006). This indicates that the average student loan debt amount more than doubled over a two-year period, while credit card balances declined. Nellie Mae (2002) found average credit card balances decreased $15 \%$.

\section{OBJECTIVES}

From a strategic marketing standpoint, there is some room for growth in the student credit card market. In order to more successfully market credit cards, information concerning patterns of usage will be useful to the credit industry. More specifically, knowledge of college student spending, bill paying and loan habits will enable credit card companies to further serve the market. To further understand these habits research was conducted. Specific objectives included the following:

1. Investigate primary reasons for usage of credit cards and loans by college students

2. Investigate reasons students apply for credit cards with certain companies

3. Investigate relationships between credit card and loan amounts

4. Investigate relationships between debt and income/job status

5. Investigate relationships between debt and GPA

6. Determine the number of credit card applications received per week by college students

7. Investigate a relationship between credit card limits and credit card debt

8. Investigate credit card bill payment timeliness

9. Investigate interest rates

\section{METHODOLOGY}

A survey procedure was employed to collect the data. The sampling method utilized was convenience sampling. The survey was conducted over a three-week period in February 2008. The data was collected at a university in the southern United States and over the Internet. Questionnaires were distributed to students at various sites around campus including the Student Union, the Library, and classroom buildings. A website was also utilized; the URL was posted on chalkboards around campus and through faculty Blackboard sites asking students to fill out the questionnaire.

\section{MEASURES}

Students that participated in the study supplied demographic and financial information along with descriptive spending habits. The data included the following: gender, age, race, GPA, school/job status and income. Financial information included credit card limits, debt, interest rates and late payments. Subjects were also asked to provide information on how many credit card applications they received per week by standard mail.

\section{FINDINGS}

Three hundred thirty-one surveys were collected and analyzed for this study. 


\section{Objective 1}

Participants that owned credit cards were asked to state their primary uses of their cards. The majority of the sample stated that its main usage was for emergency purposes followed by gasoline purchases and grocery shopping. Figure 1.1 shows that approximately $33 \%$ of individuals who own at least one card in their name have it for emergencies. Students between the ages of 20 and 22 are a major component of this group. Students that stated they had an income of less than $\$ 10,000$ were the only demographic that claimed grocery shopping as reason to use credit cards as often as being prepared for emergencies.

Respondents were also asked what was their reasoning for taking out their most recent loan. An overwhelming amount of respondents reported having outstanding loans for school. Figure 1.2 indicates that $65.6 \%$ stated their most current loan was for educational purposes followed by loans to purchase cars. Individuals between the ages of 20 and 22 were more likely have car loans (20.7\%) than others. Respondents who reported attending school full time but were unemployed incur student debt as a source of income (73.3\%).

\section{Objective 2}

One common assumption this study has was that students acquire credit cards with certain companies for the rewards received for usage. Students with credit cards were asked from which credit card company they acquired their most recent credit card. Visa was a very popular card among students with 114 responses. Figure 2.1 displays the number of students with credit cards and the sources of those cards.

Subjects with credit cards that provide rewards of some kind totaled $36.9 \%$ while those subjects who do not receive rewards totaled 29\%. The most common form of rewards was Points followed Cash Back and then Miles. Some respondents receive a combination of Points and Cash Back (1.5\%), and one student reported getting all three rewards.

The research indicates that $51.8 \%$ of the participants with a Visa card stated that they did not receive rewards. However, the majority (56.3\%) of MasterCard customers reported receiving rewards. Discover customers and customers of other firms represented the largest group (87.5\%) reporting they received rewards. American Express customers fall in second place with $66.6 \%$. Clearly, Visa card holders apparently do not have their cards for the purposes of receiving bonuses.

\section{Objective 3}

Of the students surveyed, $64.4 \%$ said they have at least one credit card and 50.8\% stated that they have a loan and $25.6 \%$ have both. This information closely parallels the results of the Nellie Mae study of college students and credit card debt. Their research showed that $66 \%$ of college students started the year with at least one credit card (Nellie Mae, 2002).

Based on the data collected, the average loan amount for college students who have both outstanding loans and credit debt is less than $\$ 5000$. Furthermore, out of students surveyed that possessed both credit card and loan debt, $84 \%$ reported having less than $\$ 2000$ in credit debt. This is slightly below the average credit card debt of college students $(\$ 2,169)$ reported by Nellie Mae $(2002)$.

The information collected does not show a significant relationship between the amount of credit card debt and the amount of outstanding loans students have. There does exist, however, a strong relationship between age and debt amounts. Students between the ages of 20-25 account for $68 \%$ of those reported having loans. Students aged $17-25$ account for $56 \%$ of those who reported having credit card debt. Figure 3.1 shows how student debt is distributed by age. 


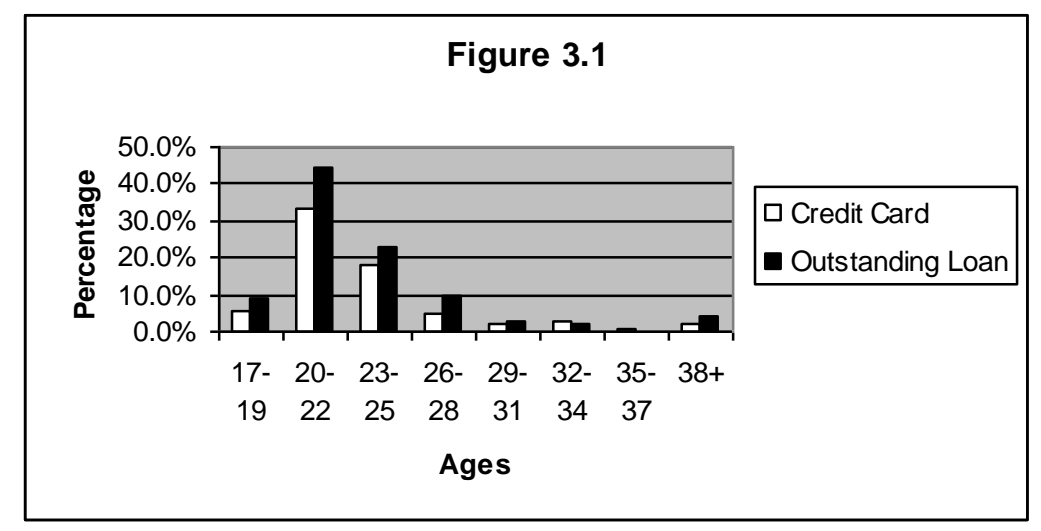

\section{Objective 4}

Nearly $80 \%$ of individuals surveyed possess less than $\$ 1,000$ in credit card debt or report they have no debt. Very few of respondents surveyed have credit card debt above $\$ 5,000(5 \%)$. The majority of people that are taking on credit card debt have a job to help pay expenses. Full time students with part time jobs make up $63 \%$ of people that owe up to $\$ 1000,62 \%$ that have credit debt between $\$ 1,000$ and $\$ 2,000$, and $45 \%$ of students that possess more than $\$ 5,000$. Twenty-eight unemployed students possess credit card debt in various amounts. Full time students are more likely to have credit card debt up to $\$ 1000$ despite job status.

Students that make more than $\$ 25,000$ possess the majority of credit card debt above $\$ 5,000$. Approximately one quarter of individuals surveyed make less than $\$ 10,000$ and do not owe on their credit cards. Another $17.5 \%$ have debt that is less than $\$ 1,000$. These two debt levels are nearly identical in the $\$ 10,000$ to $\$ 13,000$ income bracket. Twenty-five percent of students that make between $\$ 13,001$ and $\$ 16,000$ have credit card debt up to $\$ 2,000$. Individuals that have credit card debt in the $\$ 2,001-\$ 3,000$ are mainly found in the $\$ 25,001$ or more bracket $(44 \%)$.

In regards to loans, most students take out amounts under $\$ 5,000$. Forty-six percent of individuals that identified their current indebtedness stated they are within this range. Another $18 \%$ claimed to have loans totaling between $\$ 5,000$ and $\$ 10,000$. The loan brackets of $\$ 10,001-\$ 15,000$ (9.6\%) and $\$ 25,000$ or more (8.8\%) recorded figures relatively close to each other. Most full time students with part time jobs have loans that are as high as $\$ 10,000$. Oddly, the highest loan amounts reported were by students that attend school full time and work full time.

Sixty one percent of people who make up to $\$ 10,000$ take out loans up to $\$ 5,000$. Students that have incomes greater than $\$ 25,000$ take out higher loan amounts more frequently. However, there are individuals within the lower income levels that have indebtedness above their income (8\%).

\section{Objective 5}

Another relationship studied was between GPA and amount of credit card debt and outstanding loans. The data indicates of the 312 students that replied to questions regarding loans and GPA, 50.6\% have loans. The amount of students with and without loans was almost evenly distributed within the GPA ranges. Figure 5.1 indicates this distribution. 


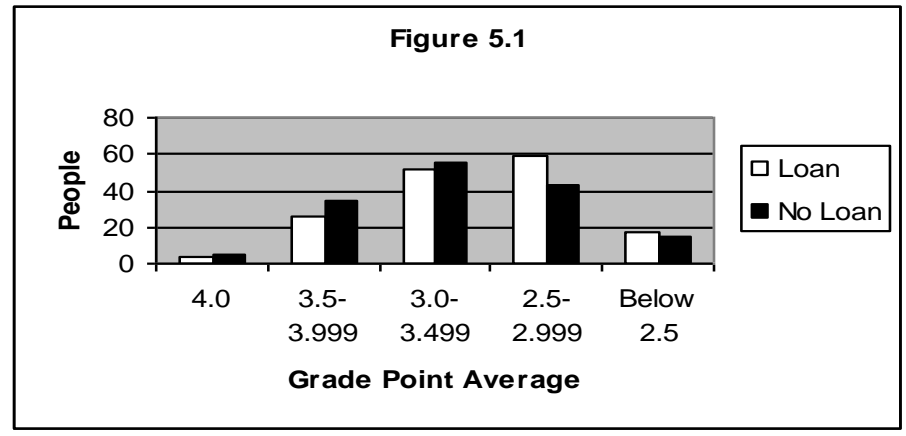

Only 195 students answered questions regarding amounts of credit card debt and GPA. Of that, $56 \%$ have credit card debt while $42 \%$ claim they do not. There appears to be a relationship between GPA and credit debt. Seventy three percent of students who said they have credit card debt report having GPAs between 2.5-3.499. The majority of students who reported not having credit debt (85\%) fall into the GPA ranges of 2.5-2.999, 3.0-3.499, and 3.5-3.999.

\section{Objective 6}

Participants were asked, on average, how many unsolicited credit card applications they receive through standard mail each week. Over half of the respondents (121) answered 1 to 3 times a week. This shows that 57.6\% of our sample receives an application at least once a week, which equals at least 52 credit card applications a year. Forty-six respondents claimed to receive applications on average 4-6 times per week, while 26 students did not receive any.

When the data was compared as a function of age and school/job status there was no meaningful difference discovered. The majority was centered at $38.2 \%$ of students with a GPA of 2.5 to 3.499 received 1 to 3 applications each week. Of the students with the highest GPA (4.0), only $1.5 \%$ received 1 to 3 applications a week and $1 \%$ received between 4 and 9 applications.

\section{Objective 7}

The data indicates that $67 \%$ of respondents that have credit cards have a credit limit of $\$ 3,000$ or less. Also, $10 \%$ do not know what their credit card limit is. The results indicate that $40 \%$ of those with credit cards do not have credit card debt. This lack of credit card debt is a result of respondents who claim they pay their balances in full each month $(45 \%)$.

There appears to be no significant indication to support the assumption that students with higher credit card limits have high credit card debt. However, the data does explain that $36 \%$ of students with a credit limit greater than $\$ 3,000$ have spent their allotted limit.

\section{Objective 8}

Most of the students in our survey are very timely when paying their credit card bill. $81 \%$ of individuals with credit cards stated they always pay their bill on time. An additional 16\% admit to paying their statement on time regularly. All age and student/job status groups show strong support for paying bills when they are due. In terms of GPA, 4.4\% of individuals that reported a 2.5-2.999 grade point average seldom pay their statement on time. Students that have an income less than $\$ 10,000$ recorded similar figures.

Approximately $60 \%$ of students with credit cards admit to never paying a late fee, while another $37 \%$ seldom made late fee payments. Surprisingly, students that admitted to paying late charges all the time were 
between the ages of 23 and 25. Most younger respondents have not paid a late charge (79\%). Students with high grade point averages tend to pay on time.

Finally, nearly $50 \%$ of respondents stated that they pay an amount that is above the minimum payment but below the total amount due. Approximately 45\% pay the entire balance due. Students between the ages of 23 and 31 tend to pay between the minimum and total balance. Students that have a GPA below 2.5 tend to pay the entire balance more often than amounts between the minimum and total amount due (59\%). Respondents that recorded grade point averages between 3.0 and 3.499 are split between paying the entire balance $(47 \%)$ and payments between the total and minimum (48\%). Students that go to school full time and work part time frequently make minimum payments on their credit card bill. Students who attend college part time and are unemployed try to pay their balances in full each month (66\%). Most respondents that pay their entire balance each month have an income under \$10,000 (58\%) whereas students that have an income above $\$ 25,000$ make payments between the two levels $(68 \%)$. Every other salary demographic has a majority of individuals that pay between the minimum and maximum.

\section{Objective 9}

The final objective in this study pertains to credit card interest rates. Participants were asked what their interest rate was on the credit card used most often. Alarmingly, 34.3\% of respondents did not know what their rates were. A number of respondents have either a very high interest rate (16.2\%) or have no interest on their card at all $(12.5 \%)$. The responses to all other choices were fairly evenly distributed.

When the data was compared as a function of age and school/job status, there were no meaningful differences discovered. However, meaningful discrepancies were found when the data was compared as a function of GPA. The majority of students in all grade point average brackets, except for the 2.5 to 2.999 GPA group, responded that they did not know their interest rate. The majority of this group stated their rate was $12 \%$ or more.

\section{LIMITATIONS}

There were two existing limitations to the research that was conducted. The ethnicity demographic was a limitation. The vast majority of the sample taken was Caucasian, and this provided a lopsided view of the population. Additionally, the study was conducted at a single university with limited locations and classrooms over a short time period. This does not permit our conclusions and recommendations to be universally relevant. This study is comparable to other research, reinforcing the significance of the findings. In order to improve marketing of credit cards to students, a comprehension of shifts in credit card debt among college students is imperative.

\section{CONCLUSION}

The results clearly indicate that students primarily use credit cards to pay for emergency situations, gasoline and grocery shopping. The majority of the sample stated that the main purpose of their most recent loan was for school tuition.

Students using credit cards with certain companies for rewards offered for usage was an assumption made before this study was conducted. After analyzing the data, more students are Visa customers and do not receive rewards for usage.

The data indicates that $64 \%$ of students have a credit card, $50 \%$ of students have a loan, and $25 \%$ admit to having both. There does not appear to be a relationship, however, between the amount of credit debt and the amount of loans.

The majority of our sample either has credit card debt under $\$ 1,000$ or none at all. Very few individuals surveyed have debt over $\$ 5,000$. Seventy-nine percent of respondents have jobs to help pay their credit card statements. Most respondents (25.5\%) have total personal income excluding loans between $\$ 1$ and \$9,999 and have no credit card debt. Students with small incomes have low outstanding loan amounts. 
Each GPA had almost the same amount of students who claimed having or not having a loan. This study assumed students with higher GPAs receive more credit card applications than others. The data indicated this was no necessarily so as students with lower GPAs appear to receive more unsolicited credit card applications.

No significant data was found to indicate that students with credit cards spend more when they have a higher credit limit. Also, $40 \%$ of respondents who have credit cards admit to having no credit debt.

The majority of our sample was very timely in paying credit card bills. Roughly $81 \%$ of students send their payment before the due date. Most have never made a late fee payment. However, the results show that it is common for students to pay a late fee once in a while. The sample is split between making payments that either equals the entire amount owed or a figure that is between the minimum and maximum payment amounts.

Our hypothesis on interest rates was that students tend to have higher rates because of the liability and expense associated with maximum balances and late fees. The data indicated that the majority of students did not know the interest rate on their credit card used most often. This result is puzzling. Students with a higher GPA are generally well informed, especially in areas of important matters. Yet, students with a GPA lower than 4.0 were more knowledgeable when it came to knowing the interest rate on their credit card.

The findings in this study are beneficial to credit card companies and loan providers that supply services to college students. The relationships discovered between age, GPA, student/job status, and personal income will give marketers a solid foundation for promotions and strategies to further capture market share amongst college students.

\section{AUTHOR INFORMATION}

Dylan Williams received a Bachelor of Science in Accounting from Southeastern Louisiana University in May of 2007. He completed his Master of Business Administration with a concentration in Marketing at the same university the following May of 2008. He will begin work as a staff auditor for KPMG in Baton Rouge, Louisiana in September of 2008 .

Tiffany Giardelli received a Bachelor of Arts in Marketing with a concentration in Advertising and Integrated Marketing Communications from Southeastern Louisiana University in December of 2006. She completed her Master of Business Administration with a major in Marketing at the same university in May of 2008. Since 2005, she has worked for Resource Bank in Covington, Louisiana and currently holds the position of Marketing Assistant.

Brian P. Waterwall will receive his MBA from Southeastern Louisiana University in Hammond, LA the Fall of '08. He is currently a Graduate Assitant in the General Business Department at Southeastern Louisiana University.

\section{REFERENCES}

1. $\quad$ Block, Sandra. "Students Suffocate Under Tens of Thousands in Loans." USA Today. 22 Accessed Feb. 2006. 27 Feb. 2008 <www.usatoday.com

2. $\quad$ Hall, John. "College Students and Credit." American Bankers Association (2008): 27-28. 4 Mar. 2008.

3. Lazarony, Lucy. "Credit Cards Teaching Students a Costly Lesson." Bankrate. 5 June 1998. Accessed 27 Feb. 2008 <http://www.bankrate.com>.

4. Palmer, Kimberly, and Emily Brandon. "The Rush to Push Plastic; Companies Use Free Food and Facebook to Lure Students." U.S. News \& World Report 28 Jan. 2008: 58. ProQuest Research Library. Sims Memorial Library, Hammond. Accessed 27 Feb. 2008. Keyword: Credit Card Companies, Marketing, College Students.

5. $\quad$ Palmer, Kimberly. "The Rise of the Debit Card; Credit Balances Dip, But Loan Debt is Growing." U.S. News \& World Report 28 Jan. 2008: 58. ProQuest Research Library. Sims Memorial Library, Hammond. Accessed 25 Feb. 2008. Keyword: College Students, Credit Card Debt. 
6. $\quad$ Silver-Greenberg, Jessica. "Majoring in Credit-Card Debit." BusinessWeek 5 Sept. 2007. Accessed 27 Feb. 2008 <www.msnbc.com>.

7. Silver-Greenberg, Jessica. "Marketing Plastic: the New College Try." Ed. Deborah Stead. BusinessWeek 15 Oct. 2007: 11. ProQuest Research Library. Sims Memorial Library, Hammond. Accessed 27 Feb. 2008. Keyword: Credit Card Companies, Marketing, College Students.

8. Simon, Ruth, and Christine Whelan. "The New Credo on Campus: 'Just Charge It'---Credit-Card Companies Target Students Before Freshman Year; Should Your Kid Get One?" The Wall Street Journal 3 Sept. 2002, Eastern ed., sec. D: 1. ProQuest Research Library. Sims Memorial Library, Hammond. Accessed 25 Feb. 2008. Keyword: credit card companies, marketing, college students.

9. $\quad$ Souccar, Miriam K. "Card Marketers Initiating a Soft Sell on Campus." American Banker 3 Sept. 1999: 1. ProQuest Research Library. Sims Memorial Library, Hammond. Accessed 25 Feb. 2008. Keyword: Credit Card Companies, Marketing, College Students.

10. "Undergraduate Students and Credit Cards; an Analysis of Usage Rates and Trends." Nellie Mae. Apr. 2002. Accessed 27 Feb. 2008 <http://www.nelliemae.com>. 